\title{
PERJANJIAN NOMINEE ANTARA WARGA NEGARA ASING DENGAN WARGA NEGARA INDONESIA DALAM PRAKTIK JUAL BELI TANAH HAK MILIK YANG DIHUBUNGKAN DENGAN PASAL 1313 KITAB UNDANG-UNDANG HUKUM PERDATA
}

\author{
oleh: \\ Ridwan Mutaqin \\ Deny Haspada
}

\begin{abstract}
ABSTRAK
Perjanjian nominee atau sering juga disebut dengan istilah perwakilan atau pinjam nama berdasarkan surat pernyataan atau surat kuasa yang dibuat kedua belah pihak dalam bentuk akta otentik, dimana warga negara asing meminjam nama warga negara Indonesia untuk dicantumkan namanya sebagai pemilik tanah pada sertifikatnya, tetapi kemudian warga negara Indonesia berdasarkan akta pernyataan yang dibuatnya mengingkari bahwa pemilik sebenarnya adalah warga negara asing selaku pihak yang mengeluarkan uang untuk pembelian tanah tersebut dan penguasaannya dilakukan atau diwakilkan kepada warga negara asing tersebut. Dalam pelaksanaannya perjanjian nominee ini dijadikan suatu celah bagi warga Negara asing untuk memiliki tanah di Negara Indonesia, dimana hal ini bertentangan dengan Undang-Undang nomor 5 tahun 1960 tentang peraturan pokok-pokok agraria. Hal ini berakibat bahwa perjanjian nominee dijadikan suatu celah bagi WNA dalam pemilikan tanah di Indonesia, dalam hal ini adalah ketentuan Pasal 21 ayat (1) dan ketentuan Pasal 26 ayat (2) UUPA, maka perjanjian nominee adalah perjanjian yang batal sejak semula, karena perjanjian nominee dibuat secara tidak sah, dengan begitu tidak mempunyai kekuatan hukum yang mengikat. Permasalahan yang dikaji dalam penelitian ini beserta tujuannya ialah untuk mengetahui pelaksanaan perjanjian nominee dan akibat hukum bagi perjanjian nominee dalam praktik jual beli. Hasil penelitian ini menunjukan bahwa perjanjian nominee ini merupakan produk cacat hukum, dikarenakan tidak memenuhi ketentuan-ketentuan yang berlaku di Indonesia, dan perjanjian nominee ini merupakan suatu upaya penyelundupan hukum, maka dari itu perjanjian nominee ini bersifat tidak mengikat dan batal bagi kedua belah pihak.
\end{abstract}

\section{PENDAHULUAN}

\section{Latar Belakang}

Pada umumnya dalam kehidupan bermasyarakat, suatu perikatan itu lahir dari suatu bentuk perjanjian yang di buat antara pihak yang saling mengikatkan diri dalam perjanjian tersebut, dan tak dapat dipungkiri pula bahwa suatu perjanjian memiliki peran penting dalam berkegiatan di dalam masyarakat baik di bidang ekonomi, sosial maupun politik. Perikatan merupakan suatu hubungan hukum, yang artinya hubungan yang diatur dan diakui oleh hukum. Hubungan hukum perlu dibedakan dengan hubungan-hubungan yang terjadi dalam pergaulan hidup berdasarkan kesopanan, kepatuhan dan kesusilaan. ${ }^{1)}$

Perjanjian dan perikatan itu merujuk pada dua hal yang berbeda, perikatan ialah suatu hal yang lebih bersifat abstrak, yang mana lebih menunjuk dalam hubungan hukum pada suatu harta kekayaan antara dua orang ataupun dua pihak atau lebih. Perikatan lebih luas dari perjanjian, yang mana tiap-tiap perjanjian adalah perikatan, tetapi perikatan belum tentu suatu perjanjian. Perjanjian ini juga akan melahirkan suatu hak dan kewajiban dalam lapangan hukum harta kekayaan bagi para pihak yang membuat perjanjian tersebut. Perjanjian adalah suatu peristiwa dimana seorang berjanji kepada seorang lain atau dimana dua orang itu saling berjanji untuk melaksanakan sesuatu hal.

1) R. Setiawan, Pokok-pokok Hukum Perikatan, Bandung, 1977, hlm 3 
Secara yuridis pengertian perjanjian diatur dalam buku ketiga Kitab Undang-Undang Hukum Perdata tentang perikatan. Definisi perjanjian menurut Pasal 1313 Kitab UndangUndang Hukum Perdata adalah suatu perbuatan dengan mana satu orang atau lebih mengikatkan dirinya terhadap satu orang lain atau lebih. Perjanjian harus memenuhi syarat sahnya perjanjian, sebagaimana yang tertuang dalam Pasal 1320 Kitab Undang-Undang Hukum Perdata, yaitu sepakat mereka yang mengikatkan dirinya, kecakapan untuk membuat suatu perikatan, suatu hal tertentu, dan suatu sebab yang halal. Terpenuhinya empat syarat sahnya perjanjian, maka secara hukum adalah mengikat bagi para pihak yang membuatnya.

Suatu perjanjian adalah semata-mata untuk suatu persetujuan yang diakui oleh hukum. Persetujuan ini merupakan kepentingan yang pokok di dalam dunia usaha dan menjadi dasar bagi kebanyakan transaksi dagang seperti jual beli barang, tanah, pemberian kredit, asuransi, pengangkutan barang, pembentukan organisasi usaha dan termasuk juga menyangkut tenaga kerja. $^{2)}$

Pada dasarnya perjanjian menurut namanya dibagi menjadi dua macam yaitu perjanjian bernama (nominaat) dan perjanjian tidak bernama (innominaat). ${ }^{3)}$

Perjanjian bernama (nominaat) adalah perjanjian khusus yang mempunyai nama sendiri, maksudnya ialah bahwa perjanjian-perjanjian tersebut diatur dan diberi nama oleh pembentuk undang-undang, berdasarkan tipe yang paling banyak terjadi sehari-hari. Perjanjian ini terdapat di dalam buku ke tiga Kitab Undang-Undang Hukum Perdata, mulai dari Bab V tentang Jual Beli sampai dengan Bab XVIII tentang Perdamaian, sedangkan yang disebut dengan perjanjian tidak bernama (Innominaat) adalah perjanjian-perjanjian yang tidak diatur dalam Kitab Undang-Undang Hukum Perdata tetapi terdapat di dalam masyarakat. ${ }^{4)}$

Istilah nominee tersebut sering disamakan dengan istilah perwakilan atau pinjam nama, berdasarkan surat pernyataan atau surat kuasa yang dibuat kedua pihak, orang asing meminjam nama WNI untuk dicantumkan namanya sebagai pemilik tanah pada sertifikatnya, tetapi kemudian Warga Negara Indonesia berdasarkan Akta Pernyataan yang dibuatnya mengingkari bahwa pemilik sebenarnya adalah orang asing selaku pihak yang mengeluarkan uang untuk pembelian tanah tersebut dan penguasaannya dilakukan atau diwakilkan kepada orang asing tersebut. Pada saat didaftarkannya menjadi dan atas nama WNI pada sertifikat Hak Milik atas tanah yang sebenarnya dibeli atau dibayar oleh orang asing tersebut maka untuk memperoleh perlindungan hukumnya, diantara orang asing dengan WNI dibuatkan perikatan dalam satu atau beberapa perjanjian dan bahkan dalam suatu akta pernyataan yang isinya menyebutkan bahwa WNI adalah orang yang hanya dipinjam namanya dalam bukti Hak Milik atas tanah (sertifikat), sedangkan pemilik sesungguhnya adalah WNA tersebut. Di Indonesia banyak sekali tempat wisata yang banyak menarik wisatawan dalam negeri maupun asing, seperti Bali yang banyak dikunjungi oleh wisatawan asing karena daerahnya yang memiliki banyak daya tarik, diantaranya adalah seni budaya yang beranekaragam dan pantaipantai indah yang tersebar di sana menjadikan Bali sebagai daerah wisata yang sangat terkenal, dalam perkembangan selanjutnya, banyak wisatawan asing yang tertarik untuk membeli tanah dan memilikinya dengan Hak Milik di daerah tersebut, baik untuk mendirikan rumah tempat tinggal maupun untuk investasi.

2) Abdul Kadir Muhammad, Hukum Perjanjian, Bandung: alumni, 2010, hlm. 93

3) Salim HS, Perkembangan Hukum Kontrak di Luar KUH Perdata, Raja Grafindo Persada, Jakarta, 2006, hlm. 1

4) Abdul Kadir Muhammad, Op. cit, hlm.93. 


\section{Identifikasi Masalah}

1. Bagaimana pelaksanaan perjanjian pinjam nama (nominee) antara Warga Negara Indonesia dengan Warga Negara Asing dalam praktik jual beli tanah Hak Milik dihubungkan dengan Pasal 21 Undang-Undang Pokok Agraria?

2. Bagaimana akibat hukum perjanjian pinjam nama (nominee) antara Warga Negara Indonesia dengan Warga Negara Asing dalam praktik jual beli tanah Hak Milik dihubungkan dengan Pasal 21 Undang-undang Pokok Agraria?

\section{TINJAUAN PUSTAKA}

\section{Pengertian Perjanjian}

Pengertian perjanjian itu sendiri, diatur dalam Buku III (tiga) dan Bab II (dua) KUH Perdata. Pasal 1313 KUH Perdata yang menyatakan: "Suatu perjanjian (persetujuan) adalah suatu perbuatan dengan mana satu orang, atau lebih mengikatkan dirinya terhadap satu orang atau lebih".

Suatu perjanjian adalah suatu peristiwa dimana seorang berjanji kepada seorang lain, atau dimana dua orang atau lebih, saling berjanji untuk melakasanakan suatu hal. ${ }^{5)}$

Perjanjian adalah sutau perbuatan/tindakan hukum yang terbentuk dengan tercapainya kata sepakat yang merupakan pernyataan kehendak bebas dari dua orang (pihak) atau lebih, di mana tercapainya sepakat tersebut tergantung dari para pihak yang menimbulkan akibat hukum untuk kepentingan pihak yang satu dan atas beban pihak yang lain atau timbal balik dengan mengindahkan ketentuan perundang-undangan. ${ }^{6}$ )

Singkatnya, perjanjian adalah perbuatan hukun yang menimbulkan, berubahnya, hapusnya hak atau menimbulkan suatu hubungan hukum dan dengan cara demikian, perjanjian menimbulkan akibat hukum yang merupakan tujuan para pihak. Jika suatu perbuatan hukum adalah perjanjian, orang-orang yang melakukan tindakan hukum disebut pihak-pihak. ${ }^{7}$

\section{Sahnya Perjanjian} yaitu: ${ }^{8)}$

Syarat-syarat untuk sahnya suatu perjanjian, disebutkan dalam Pasal 1320 KUH Perdata,

a. Sepakat mereka yang mengikat dirinya;

b. Cakap untuk membuat suatu perjanjian;

c. Suatu hal tertentu; dan

d. Suatu sebab yang halal.

Syarat pertama ialah sepakat atau dinamakan juga perizinan. Dimaksudkan bahwa kedua belah pihak yang mengadakan perjanjian itu harus sepakat atau setuju mengenai hal-hal yang pokok dari perjanjian yang diadakan itu. Sepakat yaitu kesesuaian, kecocokan, pertemuan kehendak dari yang mengadakan perjanjian atau pernyataan kehendak yang disetujui antara pihak-pihak. Unsur kesepakatan dibagi menjadi dua yaitu:9)

a. Offerte (penawaran) adalah pernyataan pihak yang menawarkan

b. Acceptasi (penerimaan) adalah pernyataan pihak yang menerima penawaran.

5) Subekti, Hukum Perjanjian, Op.Cit. hlm.1.

6) Herlien Budiono, Ajaran Umum Hukum Perjanjian dan Penerapannya di Bidang Kenotariatan, Citra Aditya Bakti, Bandung, 2011, hlm.3.

7) Ibid. hlm. 3.

8) Herlien Budiono, Ajaran Umum Hukum Perjanjian, Op.Cit, hlm. 73.

9) Mariam Darus Badrulzaman, KUH Perdata Buku III, Alumni, Bandung, 2006, hlm.98 
Kesepakatan itu penting diketahui, karena merupakan awal terjadinya perjanjian. Selanjutnya dalam Pasal 1321 KUH Perdata berbunyi "tiada sepakat yang sah apabila sepakat itu diberikan karena kekhilafan, atau diperolehnya dengan paksaan atau penipuan."

\section{Pengertian Hak Milik}

Berdasarkan ketentuan Pasal 21 Undang-Undang Nomor 5 Tahun 1960 tentang Peraturan Dasar Pokok-Pokok Agraria subjek hak milik ialah sebagai berikut:

1) Warga Negara Indonesia

2) Badan-badan hukum tertentu yang ditetapkan oleh Pemerintah

Adapun badan-badan hukum tertentu yang boleh memiliki hak milik atas tanah telah ditentukan dalam Peraturan Pemerintah No.38 Tahun 1963 tentang Penunjukan Badan-Badan Hukum Yang Dapat Mempunyai Hak Milik Atas Tanah (Lembaran Negara 1963-61). Dalam Pasal 1 ditentukan bahwa Badan-badan hukum yang dapat mempunyai hak milik atas tanah adalah:

1) Bank-bank yang didirikan oleh Negara (selanjutnya disebut Bank Negara);

2) Perkumpulan-perkumpulan Koperasi Pertanian yang didirikan berdasarkan atas Undang-Undang Nomor 79 Tahun 1958 tentang Perkumpulan Koperasi;

3) Badan-badan keagamaan, yang ditunjuk oleh Menteri Pertanian/ Agraria, setelah mendengar Menteri Agama;

4) Badan-badan Sosial yang ditunjuk oleh Menteri Pertanian/ Agraria, setelah mendengar Menteri Kesejahteraan Sosial.

Adapun yang menjadi dasar pertimbangan bahwa Badan-badan hukum tersebut dapat diberikan hak milik atas tanah adalah keperluan masyarakat yang sangat erat hubungannya dengan keagamaan, sosial dan hubungan perekonomian. Pemilikan hak atas tanah oleh badanbadan hukum tersebut sepanjang tanah tersebut diperlukan untuk usaha yang berkaitan langsung dengan bidang sosial dan keagamaan. ${ }^{10)}$

Bagi warga negara asing dan badan hukum asing tidak diperkenankan untuk memperoleh hak milik atas tanah. Hal ini tercermin dalam ketentuan Pasal 21 ayat (3) Undang-Undang Nomor 5 Tahun 1960 tentang Peraturan Dasar Pokok-Pokok Agraria yang menyatakan:

"Orang asing yang sesudah berlakunya Undang-undang ini memperoleh hak milik karena pewarisan tanpa wasiat atau percampuran harta karena perkawinan, demikian pula warganegara Indonesia yang mempunyai hak milik dan setelah berlakunya undang-undang ini kehilangan kewarganegaraannya wajib melepaskan hak itu dalam jangka waktu satu tahun sejak diperolehnya hak tersebut atau hilangnya kewarganegaraan itu. Jika sesudah jangka waktu tersebut lampau hak milik itu tidak dilepaskan, maka hak tersebut hapus karena hukum dan tanahnya jatuh pada negara, dengan ketentuan bahwa hak-hak pihak lain yang membebaninya tetap berlangsung."

Demikian pula bagi warga negara ganda tidak diperkenankan untuk memiliki tanah dengan hak milik. Hal ini sesuai dengan ketentuan Pasal 21 ayat (4) Undang-Undang Nomor 5 Tahun 1960 tentang Peraturan Dasar Pokok-Pokok Agraria yang menyatakan "Selama seseorang di samping kewarganegaraan Indonesianya mempunyai kewarganegaraan asing maka ia tidak dapat mempunyai tanah dengan hak milik dan baginya berlaku ketentuan dalam ayat 3 pasal ini".

Ketentuan-ketentuan tersebut menunjukkan baik warga negara asing maupun warga negara Indonesia yang memiliki kewarganegaraan ganda dengan kewarganegaraan asing tidak dibolehkan untuk memiliki tanah dengan hak milik di Indonesia.

10) Ibid, hlm. 98-99 
Penguasaan/kepemilikan tanah hak milik oleh orang asing bertentangan dengan asas nasionalitas yang dianut oleh Undang-Undang No 5 Tahun 1960 Tentang Peraturan Dasar Pokok-Pokok Agraria. Prinsip dari asas nasionalitas menetapkan hanya Warga Negara Indonesia saja yang mempunyai hubungan sepenuhnya dengan bumi, air, dan angkasa. ${ }^{11}$

Penerapan asas nasionalitas dalam Undang-Undang Nomor 5 Tahun 1960 tentang Peraturan Dasar Pokok-Pokok Agraria, terutama dalam kepemilikan hak atas tanah, memberikan konsekuensi adanya perbedaan perlakuan antara warga negara Indonesia dengan warga negara asing. Penguasaan/kepemilikan tanah hak milik oleh orang asing, bisa berdampak negatif, baik bagi Bangsa dan Negara Indonesia, apalagi kalau penguasaannya itu belum ada batas-batasnya. Kondisi demikian dapat berakibat kedaulatan wilayah Negara Republik Indonesia berpotensi jatuh pada orang asing. ${ }^{12)}$

\section{Praktik Pelaksanaan Perjanjian Nominee}

Praktiknya perjanjian nominee antara WNA dengan WNI dikaitkan dengan praktik jual beli tanah hak milik kerap kali terjadi di Indonesia, khususnya didaerah-daerah pariwisata, seperti di Bali yang menarik wisatawan Asing maupun dalam Negeri, berikut adalah contoh kasus yang terjadi dalam praktik jual beli tanah hak milik:

A. Putusan Nomor 193/PDT/2015/PT.DPS. Putusan ini adalah putusan final, dimana awalnya terjadi pertikaian antara Kartika Wati (WNI) dengan Alain Maurice Pons (WNA) dan Eddy Nyoman Winarta,S.H., (Notaris/PPAT) atas suatu kepemilikan sebidang tanah yang telah dibeli pada tanggal 12 Juni 2007. Objek tersebut terletak di Jalan Jantuk Angsa, Desa Perenan, Kecamatan Mengwi, Kabupaten Badung, Propinsi Bali, kemudian pada tahun 2008 di atas tanah tersebut telah dibangun sebuah Villa dengan Nama Emmanuelle yang akan disewakan, serta hasil dari Villa terebut akan dibagi bersama, WNA tersebut akhirnya membuat Akta-Akta atas tanah tersebut di Kantor Eddy Nyoman Winarta,S.H., (Notaris/PPAT), akta-akta tersebut adalah;

1) Akta Notaris tentang Sewa Menyewa Nomor 89 tanggal 24 Maret 2008 dimana WNI yang menyewakan kepada WNA;

2) Akta Notaris tentang Pengakuan Hutang Nomor 90 tanggal 24 Maret 2008 dimana WNA sebagai pihak yang menghutangkan, dan WNI sebagai pihak yang berhutang;

3) Akta notaris tentang Pernyataan dan Kuasa Nomor 91 tanggal 24 Maret 2008 dimana WNI memberi pernyataan dan memberikan kuasa kepada WNA;

4) Akta Pemberian Hak Tanggungan Nomor 01 April 2008 atas Nama Alain Maurice Pons;

Akta-akta tersebut merupakan bentuk Akta Perjanjian Nominee yang bertujuan memindahkan hak milik tidak secara langsung kepada WNA, dengan tujuan memiliki aset-aset tanah/property khususnya di pulau Bali. Penguasaan hak atas tanah oleh WNA menunjukan secara tidak langsung melalui pejanjian notariil, telah terjadi penyelundupan hukum. Kemudian dikarenakan adanya ketidakharmonisan antara WNI dan WNA tersebut terjadilah pertikaian diantara mereka yang dimana WNI menggugat WNA dan Pihak Notaris yang berujung di persidangan, dalam persidangan tersebut keluarlah Putusan Pengadilan Negeri Denpasar Nomor 787/Pdt.G/2014/PN.Dps tanggal 18 Juni 2015 yang mengabulkan sebagian gugatan WNI terhadap WNA dan Notarisnya, putusan tersebut membatalkan 4 (empat) Akta Notaris yang telah dibuat. Kemudian pada tanggal 2 Juli 2015 WNA bersama

11) Martin Roestamy, Op. cit, hlm. 96.

12) FX. Sumarja, Hak Atas Tanah Bagi Orang Asing, STPN Press, Yogyakarta, hlm.14. 
Notarisnya mengajukan permohonan banding atas Putusan Pengadilan Negeri Denpasar Nomor 787/Pdt.G/2014/PN.Dps tanggal 18 Juni 2015 di Pengadilan Tinggi Denpasar, upaya banding tersebut diterima oleh Pengadilan Tinggi Denpasar, akan tetapi upaya tersebut malah memperkuat Putusan Nomor 787/Pdt.G/2014/PN.Dps, karena dalam proses pemeriksaan perkara terungkap pelanggaran hukum yang sebelumnya tidak terungkap, hal ini kemudian lebih memberatkan Pihak WNA dan Notarisnya.

\section{Pelaksanaan Perjanjian Nominee}

Pelaksanaan Perjanjian Nominee ini kebanyakan terjadi melalui suatu perkawinan dan juga kekerabatan, dimana WNA menikahi WNI, WNI ini ditujukan untuk membeli sebidang tanah dengan namanya, kemudian setelah diadakannya pembelian sebidang tanah barulah dibuatkan akta-akta otentik yang dibuat dihadapan Notaris, dimana akta tersebut bertujuan untuk memberikan segala kewenangan yang mungkin timbul dalam hubungan hukum terhadap tanahnya langsung kepada WNA, sehingga perjanjian tersebut menjadi bukti kepemilikan yang tidak secara langsung dimiliki oleh WNA, akta tersebut merupakan perwujudan dari Perjanjian Nominee.

Perwujudan nominee ini ada pada surat perjanjian yang dibuat oleh para pihak, yaitu antara WNA dan WNI sebagai pemberi kuasa (nominee) yang diciptakan melalui satu paket perjanjian itu pada hakikatnya bermaksud untuk memberikan segala kewenangan yang mungkin timbul dalam hubungan hukum antara seseorang dengan tanahnya kepada WNA untuk bertindak layaknya seorang pemilik yang sebenarnya dari sebidang tanah yang menurut hukum di Indonesia tidak dapat dimilikinya yaitu hak milik. Pemberian kuasa tersebut merupakan perjanjian dengan mana seorang memberikan kekuasaan (wewenang) kepada seorang lain, yang menerimanya, untuk atas namanya menyelenggarakan suatu urusan.

Mengenai kasus yang telah dibahas perjanjian nominee itu berupa akta-akta Pengakuan Hutang, Akta Kuasa dan Pernyataan, Akta Pengakuan Tentang Kepemilikan Tanah, Akta Sewa Menyewa, Akta Pemberian Hak Tanggungan, dan dalam isi akta tersebut terdapat unsur-unsur yang tidak masuk akal dan tidak adil, dalam kasus yang terjadi selaku Notaris berlaku tidak adil, dimana hal ini termuat dalam salah satu akta pengakuan hutang yang isi pokoknya menyebutkan: "pengembalian hutang baru dapat dilakukan oleh pihak WNI apabila ditagih oleh pihak WNA dan jumlah hutang hanya dapat dibayar melalui penjualan tanah yang dijadikan jaminan hutang", dalam hal ini Notaris pun harus mempertanggungjawabkan atas akta-akta yang dibuatnya, dalam pelaksanaannya perjanjian pinjam nama (nominee) biasanya dilakukan oleh WNA yang bertujuan untuk mendirikan suatu villa/penginapan, yang bermaksud untuk mencari suatu keuntungan, namun karena banyaknya kebijakan di dalam hukum pertanahan yang menganut asas nasionalitas menyebabkan WNA memiliki keterbatasan-keterbatasan tertentu di dalam memiliki rumah dan bangunan gedung di Indonesia terutama Hak Milik, oleh karena itu banyak WNA berusaha untuk memperoleh hak milik atas tanah di Indonesia dengan menggunakan cara yang dilarang oleh undang-undang yaitu dengan melakukan perjanjian nominee atau pinjam nama, WNA memanfaatkan perjanjian nominee ini sebagai bukti kepemilikan tanah hak milik di Indonesia walaupun tidak secara langsung nama yang tercantum dalam sertipikat adalah nama WNA, hal itu dibuktikan dari kasus-kasus yang ada, kebanyakan perjanjian nominee ini terjadi di tempat-tempat wisata di Indonesia, seperti di Bali. 


\section{PEMBAHASAN}

\section{Akibat Hukum Perjanjian Nominee Antara Warga Negara Asing dengan Warga Negara Indonesia}

Praktik Perjanjian Nominee yang bertujuan untuk menghindari peraturan perundangundangan adalah merupakan salah satu cara WNA untuk menguasai tanah-tanah di Indonesia, hal ini berakibat adanya suatu tindakan hukum karena bertentangan dengan peraturan perundang-undangan, hal ini dapat membatalkan Perjanjian Nominee tersebut dan merugikan WNA, tetapi meskipun kekuatan hukum WNA diposisi ini sangatlah lemah dalam Praktiknya masih saja banyak terjadi, sayangnya hanya sedikit yang terungkap oleh Negara.

Dengan melalui perjanjian, pihak-pihak dapat membuat segala macam perikatan, sesuai dengan asas kebebasan berkontrak yang terkandung dalam Buku III KUH Perdata. Walaupun terdapat asas kebebasan berkontrak tersebut, bukan berarti boleh membuat perjanjian secara bebas, melainkan harus memenuhi syarat-syarat tertentu, untuk sahnya suatu perjanjian. Syarat-syarat untuk sahnya suatu perjanjian, disebutkan dalam Pasal 1320 KUH Perdata, yaitu:

1) Sepakat mereka yang mengikat dirinya;

2) Cakap untuk membuat suatu perjanjia;

3) Suatu hal tertentu; dan

4) Suatu sebab yang halal.

Apabila syarat-syarat ini tidak dipenuhi, maka perjanjian ini batal demi hukum. Pada salah satu kasus yang terkait diputuskan bahwa akta-akta yang membebani tanah yang menjadi obyek Perjanjian Nominne adalah batal karena terdapat unsur penyelundupan hukum dimana hal tersebut tidak memenuhi syarat sah perjanjian yang tertuang dalam Pasal 1320 KUH Perdata, untuk syarat-syarat sahnya perjanjian mengenai suatu sebab yang halal yang juga merupakan syarat tentang isi perjanjian sebagaimana yang disebutkan dalam Pasal 1335 yang menyatakan "suatu perjanjian tanpa sebab, atau yang telah dibuat karena sesuatu sebab, yang palsu atau terlarang, tidak mempunyai kekuatan". Pasal ini juga sebenarnya hanya mempertegas kembali tentang salah satu syarat objektif dari keabsahan perjanjian, yaitu mengenai sebab yang halal yang terkandung dalam Pasal 1320 KUH Perdata, di mana kalau suatu perjanjian bertentangan dengan undang-undang, kesusilaan atau ketertiban umum, maka perjanjian tersebut tidak mempunyai kekuatan atau yang lazim disebut batal demi hukum. Selanjutnya dalam Pasal 1337 menyatakan "suatu sebab adalah terlarang, apabila dilarang oleh undang-undang, atau apabila berlawanan dengan kesusilaan baik atau ketertiban umum." Maksud dari pasal tersebut ialah suatu sebab dinyatakan terlarang atau biasa disebut sebab tidak halal apabila bertentangan dengan undang-undang, kesusilaan dan ketertiban umum.

Larangan untuk melakukan perbuatan hukum pemindahan hak yang mengakibatkan tanah hak milik beralih kepemilikannya kepada pihak yang bukan merupakan subyek hak milik diatur secara tegas dalam pasal 26 ayat 2 Undang-Undang Pokok Agraria. Pasal 26 ayat 2 Undang-Undang Pokok Agraria menentukan;

"Setiap jual beli ... perbuaatn-perbuatan lain yang dimaksudkan untuk langsung atau tidak langsung memindahkan hak milik kepada orang asing, kepada seorang warga negara yang disamping kewarganegaraan Indonesianya mempunyai kewarganegaraan asing atau kepada suatu badan hukum, kecuali yang ditetapkan oleh Pemerintah"

Yang termaksud dalam Pasal 21 ayat 2, adalah batal karena hukum dan tanahnya jatuh pada Negara, dengan ketentuan bahwa hak-hak pihak lain yang membebaninya tetap berlangusng serta semua pembayaran yang telah diterima oleh pemilik tidak dapat dituntut kembali."

Berdasarkan ketentuan pasal 26 ayat 2 Undang-Undang Pokok Agraria jelas bahwa tidak boleh atau dilarang melakukan perbuatan hukum berupa apapun juga, baik secara 
langsung maupun tidak langung bermaksud untuk memindahkan hak milik kepada orang asing, dengan akibat hukum seperti disebutkan di atas. Termasuk yang dilarang dalam ketentuan pasal 26 ayat 2 Undang-Undang Pokok Agraria tersebut adalah jika kita membuat kuasa atau perjanjian yang bersifat pemberian hak sepenuhnya kepada orang asing yang mengakibatkan ia mempunyai kewenangan seperti seorang pemilik atau membuat jual beli tanah yang diikuti pembuatan pernyataan pemilikan tanah (nominee).

Dalam hal ini mengakibatkan pula Notaris yang bertentangan dengan Undang-Undang, yaitu Undang-Undang Nomor 2 tahun 2014 Tentang Jabatan Notaris Khususnya Pasal 16 Ayat (1) huruf (a) yang menyatakan:

"dalam menjalankan jabatannya, Notaris wajib bertindak amanah, jujur, saksama, mandiri, tidak berpihak, dan menjaga kepentingan pihak".

Karena Notaris disini hanya mementingkan kepentingan WNA dan berpihak pada WNA saja dalam pembuatan akta-akta perjanjian nominee tersebut. Notaris dapat dimintakan pertanggungjawaban terhadap pembuatan akta yang merupakan perbuatan melawan hukum secara Perdata. Akta Nominee yang dibuat oleh Notaris dapat dikatakan sebagai suatu perbuatan melawan hukum yang juga dilakukan oleh para pihak dalam akta tersebut, karena perbuatan ini mengadung unsur melanggar ketertiban umum, perbuatan melawan hukum ini berbentuk penyelundupan hukum. Perbuatan ini juga jelas telah melanggar hukum dan ketentuan Undang-undang yang berlaku karena akta tersebut dapat digunakan untuk mendapatkan tanah oleh WNA, hal ini sangat jelas bahwa perbuatan tersebut dikatan sebagai perbuatan melawan hukum karena mengandung unsur-unsur dari perbuatan melawan hukum berdasarkan Pasal 1365 KUHPerdata.

\section{PENUTUP}

\section{Kesimpulan}

Pelaksanaan perjanjian nominee pada umumnya dilaksanakan melalui perkawinan dan kekerabatan, namun yang seringkali yang terjadi yaitu melalui perkawinan, dimana WNI menikah dengan WNA dan kemudian WNI ini membeli sebidang tanah dalam bentuk kepemilikan Hak Milik, pembelian tanah tersebut dibayar oleh WNA, kemudian dibuatkanlah akta-akta yang membebani sertipikat hak milik tersebut yang dimana akta tersebut menyatakan bahwa secara tidak langsung dimiliki/dikuasai oleh WNA, akta tersebut sebagai perwujudan perjanjian nominee.

Akibat hukum yang timbul dengan adanya perjanjian pinjam nama (nominee) dalam hal kepemilikan hak atas tanah di Indonesia adalah batal karena tidak memenuhinya syarat sah perjanjian yang termuat pada Pasal $1320 \mathrm{KUH}$ Perdata dimana isi dari perjanjian nominee ini tidak berdasarkan suatu sebab yang halal melainkan mengandung unsur-unsur perbuatan melawan hukum karena telah bertentangan dengan Undang-Undang Pokok Agraria, khususnya Pasal 21 Ayat (1), dan untuk Notaris selaku pembuat akta Perjanjian Nominee harus mempertanggungjawabkan akta yang dibuatnya karena hal tersebut termasuk perbuatan melawan hukum.

\section{Saran}

Sebaiknya dibuatkan peraturan khusus yang tegas dan jelas untuk mengatur tentang Perjanjian Nomine dalam hal kepemilikan tanah oleh WNA, masalah tersebut tentunya tidak bisa dibiarkan begitu saja, karena penguasaan atau kepemilikan tanah Hak Milik oleh orang asing melalui perjanjian nominee bisa berdampak negatif bagi Bangsa dan Negara Indonesia apalagi kalau penguasaannya itu belum ada batas-batasnya, selain itu sebaiknya pemerintah melakukan sosialisasi terhadap masyarakat tentang perjanjian nominee ini agar kedepannya dapat meminimalisasikan permasalahan tentang perjanjian nominee serta peran bagi 
masyarakat yang mengetahui tentang akta kepemilikan Perjanjian Nominee untuk melaporkan kepada pihak-pihak yang terkait, dan kepada masyarkat yang menjadi korban agar melaporkan karena dengan adanya Perjanjian Nominee itu Negara dan Korban dirugikan dalam banyak hal.

Bagi Pejabat Notaris/PPAT selaku pelaksana Undang-undang, agar memegang teguh dan melaksanakan sumpah/janji jabatan yang diucapkan sebelum memulai tugas dan jabatannya sebagai bentuk tanggung jawab kepada Negara Republik Indonesia sehingga lebih menjungjung tinggi peraturan perundang-undangan yang berlaku, jangan sampai menghalalkan segala cara yang merugikan pihak lain dan merugikan Negara

\section{DAFTAR PUSTAKA}

Abdul Kadir Muhammad, Hukum Perjanjian. PT Citra Aditya Abadi, Bandung, 1992.

FX. Sumarja, Hak Atas Tanah Bagi Orang Asing, STPN Press, Yogyakarta, 2015

Mariam Darus Badrulzaman, KUH Perdata Buku III, PT. Alumni, Bandung, 2006.

Martin Roestamy, Konsep-Konsep Hukum Kepemilikan Properti Bagi Asing, PT. Alumni, Bandung, 2011.

R. Setiawan, Pokok-pokok Hukum Perikatan. PT Alumni, Bandung 1977

Salim HS, Perkembangan Hukum Kontrak di Luar KUH Perdata, Raja Grafindo Persada, Jakarta, 2006

Salim HS , Perkembangan Hukum Kontrak di Luar KUH Perdata, PT Raja Grafindo Persada, Jakarta, 2006

Subekti, Hukum Perjanjian, PT. Intermasa, Jakarta, 2005. 